\title{
Full-term development of enucleated mouse oocytes fused with embryonic stem cells from different cell lines
}

\author{
T. Amano, Y. Kato and Y. Tsunoda* \\ Laboratory of Animal Reproduction, College of Agriculture, Kinki University, \\ Nara 631-8505, Japan
}

The developmental potential of enucleated mouse oocytes receiving embryonic stem cells from ten lines with either the same or different genetic backgrounds using the cell fusion method was examined in vitro and in vivo. The development of nuclear-transferred oocytes into blastocysts was high (34-88\%). However, there was no clear correlation between development into blastocysts after nuclear transfer and the chimaera formation rate of embryonic stem cells.

\section{Introduction}

Amano et al. (2001) reported obtaining two male mice after transfer of enucleated oocytes fused with embryonic stem cells synchronized at the metaphase; however, the mice died soon after birth. The reasons for the postnatal death are thought to be insufficient reprogramming of nuclei, epigenetic modifications of nuclei during establishment of cell lines or the effect of embryonic stem cell cytoplasm introduced into enucleated oocytes. Rideout et al. (2000) reported that young obtained after nuclear transfer of an F1 (129 SvJae $\times$ C57BL/6) embryonic stem cell line developed into adults when a direct injection method in which a small volume of cytoplasm was incorporated into enucleated oocytes was used, but all the young obtained from inbred 129 embryonic stem cells died within $24 \mathrm{~h}$ after birth. In the present study, the development of enucleated oocytes receiving embryonic stem cells from cell lines with either different or the same genetic backgrounds using the cell fusion method was compared.

\section{Materials and Methods}

Donor embryonic stem cells

A total of ten embryonic stem cell lines were used, all with the male genotype, sexed using the PCR method. Seven lines (NARA 6-12) were established in our laboratory from blastocysts of F1 (C57BL/6 $\times$ C3H, Gpi-1 b/b) females mated with F1 males as described by Amano et al. (2000) and were used within ten passages. R1 is an outbred cross with a 129 background $(129 / \mathrm{J} \times 129 / \mathrm{Sv}-\mathrm{CP}$, Gpi-1 a/a)

*Correspondence

Email: tsunoda@nara.kindai.ac.jp
The development into live young was low (1-3\%) in all cell lines and 14 of 19 young died shortly after birth. Most of the live young had morphological abnormalities. Of the five remaining mice, two died at days 23 and 30 after birth, but the other three mice are still active at days 359 (mouse 1) and 338 (mice 4 and 5) after birth, with normal fertility. However, the reasons for the abnormalities and postnatal death of embryonic stem cell-derived mice are unknown.

(Nagy et al., 1990). NR2 was established from blastocysts of ROSA 26 transgenic mice (Friedrich and Soriano, 1991) with an inbred 129/Sv background (Gpi-1 a/a), and the green embryonic stem line (D3C $\times$ NEGFP-01) is one of the embryonic stem lines established from blastocysts with a 129/Sv background by transfecting pC $\times$ NEGFP $($ pC $\times$ EGFP containing the MC-1 Ne0-Poly A cassette) (Okabe et al., 1997). These three embryonic stem lines were used at passages 17-23.

The cell cycle of embryonic stem cells was synchronized to the metaphase before nuclear transfer by culturing them with $3 \mu \mathrm{g}$ nocodazole $\mathrm{ml}^{-1}$ (Aldrich Chemical Co, St Louis, MO) in Dulbecco's modified Eagle's medium (DMEM; Nissui Co, Tokyo) supplemented with $10 \%$ fetal calf serum (Gibco, MD) and $1000 \mathrm{U}$ leukaemia inhibitory factor (Gibco) for $3 \mathrm{~h}$ at $37^{\circ} \mathrm{C}$ (Amano et al., 2001). The metaphase plate in each embryonic stem cell was confirmed using an inverted microscope with Nomarski optics during nuclear transfer.

\section{Nuclear transfer}

The chromosomes at the second metaphase of unfertilized eggs recovered from superovulated $\mathrm{F} 1$ females 13.5-15.0 h after injection of 5 iu hCG (Sankyo Co, Tokyo) were removed mechanically and enucleated oocytes were used as recipient cytoplasm (Tsunoda and Kato, 1997). A single metaphase embryonic stem cell was fused with an enucleated oocyte using inactivated Sendai virus, kindly donated by Y. Kaneda, $B \sum$ Osaka University, Japan. Fused oocytes were cultured in M16 medium (Whittingham, 1971) supplemented with $5 \mu \mathrm{g}$ cytochalasin B ml-1 (Aldrich Chemical Co) $1 \mathrm{~h}$ before activation. Two different methods were used for the activation: (i) oocytes were stimulated with a direct current of $150 \mathrm{~V} \mathrm{~mm}^{-1}$ pulsed for $50 \mu \mathrm{s}$ and $50 \mathrm{~V} \mathrm{~mm}^{-1}$ for $50 \mu \mathrm{s}$ at 20 min intervals (Kato et al., 1999); 
Table 1. Developmental ability of enucleated mouse oocytes receiving embryonic stem cells

\begin{tabular}{|c|c|c|c|c|c|c|c|c|}
\hline Cell line & $\begin{array}{l}\text { Method for } \\
\text { activation }\end{array}$ & $\begin{array}{c}\text { Number of } \\
\text { oocytes } \\
\text { fused/used (\%) }\end{array}$ & $\begin{array}{l}\text { Number of oocytes } \\
\text { developed into } \\
\text { blastocysts/cultured } \\
(\%)\end{array}$ & $\begin{array}{l}\text { Number of } \\
\text { blastocysts } \\
\text { transferred }\end{array}$ & $\begin{array}{l}\text { Number of } \\
\text { placentas } \\
\text { only } \\
(\%)\end{array}$ & $\begin{array}{l}\text { Number of } \\
\text { dead } \\
\text { fetuses } \\
(\%)\end{array}$ & $\begin{array}{c}\text { Number of } \\
\text { live } \\
\text { offspring (\%) }\end{array}$ & $\begin{array}{l}\text { Number of } \\
\text { surviving } \\
\text { mice }\end{array}$ \\
\hline \multirow[t]{2}{*}{ NARA 6} & Electric & $75 / 92(82)^{\mathrm{ab}}$ & $36 / 66(55)^{\mathrm{a}}$ & 33 & 0 & $1(3)$ & $1(3)$ & 1 \\
\hline & $\mathrm{Sr}^{2+}$ & $113 / 132(86)^{\mathrm{a}}$ & $63 / 109(58)^{\mathrm{a}}$ & 58 & 0 & 0 & 0 & - \\
\hline \multirow[t]{2}{*}{ NARA 7} & Electric & $91 / 115(79)^{\mathrm{ab}}$ & $51 / 83(61)^{\mathrm{a}}$ & 47 & 0 & 0 & 0 & - \\
\hline & $\mathrm{Sr}^{2+}$ & $84 / 123(68)^{b}$ & $52 / 82(63)^{a}$ & 52 & 0 & 0 & $1(2)$ & 0 \\
\hline \multirow[t]{2}{*}{ NARA 8} & Electric & $85 / 140(61)^{b}$ & $36 / 78(46)^{b}$ & $58^{*}$ & 0 & 0 & 0 & - \\
\hline & $\mathrm{Sr}^{2+}$ & $180 / 260(69)^{b}$ & $58 / 171(34)^{b}$ & 37 & 0 & $1(3)$ & $1(3)$ & 0 \\
\hline \multirow[t]{2}{*}{ NARA 9} & Electric & $136 / 175(78)^{\mathrm{ab}}$ & $79 / 127(62)^{\mathrm{a}}$ & 75 & 0 & 0 & $1(1)$ & 1 \\
\hline & $\mathrm{Sr}^{2+}$ & $196 / 233(84)^{\mathrm{a}}$ & $144 / 192(75)^{\mathrm{c}}$ & 115 & $3(3)$ & $1(1)$ & $1(1)$ & 1 \\
\hline \multirow[t]{2}{*}{ NARA 10} & Electric & $142 / 209(68)^{b}$ & $105 / 131(80)^{\mathrm{c}}$ & 92 & 0 & 0 & $1(1)$ & 0 \\
\hline & $\mathrm{Sr}^{2+}$ & $198 / 258(77)^{b}$ & $163 / 189(86)^{\mathrm{c}}$ & $170^{*}$ & $7(4)$ & 0 & $2(1)$ & 0 \\
\hline \multirow[t]{2}{*}{ NARA 11} & Electric & $123 / 159(77)^{b}$ & $98 / 112(88)^{\mathrm{c}}$ & 82 & 0 & 0 & 0 & - \\
\hline & $\mathrm{Sr}^{2+}$ & $131 / 166(79)^{\mathrm{ab}}$ & $106 / 126(84)^{\mathrm{c}}$ & 82 & $4(5)$ & 0 & $2(2)$ & 0 \\
\hline \multirow[t]{2}{*}{ NARA 12} & Electric & $155 / 208(75)^{b}$ & $76 / 130(58)^{\mathrm{a}}$ & 66 & $2(3)$ & 0 & 0 & - \\
\hline & $\mathrm{Sr}^{2+}$ & $142 / 179(79)^{\mathrm{ab}}$ & $101 / 138(73)^{\mathrm{c}}$ & 57 & $2(4)$ & 0 & $1(2)$ & 0 \\
\hline \multirow[t]{2}{*}{ R1 } & Electric & $328 / 530(62)^{b}$ & $173 / 300(58)^{\mathrm{a}}$ & 167 & $2(1)$ & $2(1)$ & $2(1)$ & 0 \\
\hline & $\mathrm{Sr}^{2+}$ & $254 / 306(83)^{\mathrm{ab}}$ & $106 / 251(42)^{b}$ & $165^{*}$ & $11(7)$ & $4(2)$ & 0 & - \\
\hline EGFP & Electric & $392 / 575$ & $166 / 363(46)^{b}$ & $182^{*}$ & $1(1)$ & 0 & 0 & - \\
\hline NR 2 & Electric & $795 / 992(80)^{\mathrm{ab}}$ & $394 / 725(54)^{\mathrm{a}}$ & 365 & $9(3)$ & 0 & $6(2)$ & 2 \\
\hline
\end{tabular}

${ }^{a b c}$ Values in the same column with different superscripts are significantly different $(P<0.05)$.

*Including morulae.

or (ii) oocytes were cultured in $\mathrm{Ca}^{2+}$-free $\mathrm{CZB}$ medium containing $10 \mathrm{mmol} \mathrm{Sr}^{2+} \mathrm{I}^{-1}$ for $5 \mathrm{~h}$ (Wakayama et al., 1998). The oocytes with one pronucleus and a second polar body were considered to have diploid chromosome constitution during examination $5 \mathrm{~h}$ after activation and were cultured for 4 days in M16 medium in 5\% $\mathrm{CO}_{2}: 95 \%$ air at $37^{\circ} \mathrm{C}$ (Amano et al., 2001).

Blastocysts, including a small number of morulae, that developed from nuclear-transferred oocytes were transferred to oviducts of day 1 pseudopregnant or pregnant albino CD-1 strain female mice whose GPI type was fixed to $\mathrm{a} / \mathrm{a}$ or $\mathrm{b} / \mathrm{b}$. The mice were killed on day 19.5 to examine potential for development into fetuses. Living young were fostered carefully to other females.

\section{Results}

When 10-15 embryonic stem cells were injected into blastocysts and transferred to recipient mice, chimaeric mice were obtained at rates of $75 \%$ for NARA $6,38 \%$ for
NARA $7,89 \%$ for NARA $8,43 \%$ for NARA $9,44 \%$ for NARA $10,57 \%$ for NARA $11,52 \%$ for NARA $12,71 \%$ for R1, $50 \%$ for EGFP and $62 \%$ for NR2.

The proportion of oocytes that fused with embryonic stem cells was not very different among cell lines (61-86\%), although there was a significant reduction in some cases (Table 1). Most of the oocytes formed one pronucleus with a second polar body after parthenogenetic activation $(88-98 \%)$. The proportion of nuclear-transferred oocytes that developed into blastocysts was significantly different among cell lines; the developmental potential was high in NARA 10 and 11 lines (80-88\%), but low in NARA 8 and EGFP lines (34-46\%). There was no clear correlation between development into blastocysts after nuclear transfer and chimaera formation rate of embryonic stem cells. The proportion of nuclear-transferred oocytes that developed into blastocysts was not significantly different between strontium-treated and electrically stimulated groups. In the NARA 9 and 12 lines, the developmental potential of nuclear-transferred oocytes activated with strontium was 
Table 2. Details of fetuses alive at birth

\begin{tabular}{|c|c|c|c|c|}
\hline $\begin{array}{l}\text { Mouse } \\
\text { number }\end{array}$ & $\begin{array}{l}\text { Cell } \\
\text { line }\end{array}$ & $\begin{array}{c}\text { Body } \\
\text { weight }(\mathrm{g})\end{array}$ & $\begin{array}{c}\text { Mass of } \\
\text { placenta }(\mathrm{g})\end{array}$ & Remarks \\
\hline 1 & NARA 6 & 1.20 & 0.264 & Still alive at day 359 after birth \\
\hline 2 & NARA 7 & 1.89 & 0.39 & $\begin{array}{l}\text { Died on day } 1 \text {; abdominal distension and subcutaneous haemorrhage, abdominal } \\
\text { hernia, half open eye }\end{array}$ \\
\hline 3 & NARA 8 & 1.20 & 0.29 & Died on day 1 \\
\hline 4 & NARA 9 & 1.34 & 0.20 & Still alive at day 338 after birth \\
\hline 5 & & 1.28 & 0.20 & Still alive at day 338 after birth \\
\hline 6 & NARA 10 & 1.75 & 0.29 & Died 30 min after birth; abdominal distension and subcutaneous haemorrhage \\
\hline 7 & & 1.25 & 0.32 & Died on day 1 ; abdominal subcutaneous haemorrhage \\
\hline 8 & & 1.12 & 0.23 & Died on day 1 \\
\hline 9 & NARA 11 & 1.36 & 0.24 & Died on day 1 ; abdominal distension and subcutaneous haemorrhage \\
\hline 10 & & 1.14 & 0.22 & Died on day 1 \\
\hline 11 & NARA 12 & 0.76 & 0.27 & Died 30 min after birth \\
\hline 12 & R1 & 1.79 & 0.31 & Died on day 2 ; abdominal distension and subcutaneous haemorrhage \\
\hline 13 & & 1.44 & 0.17 & Died on day 1 ; short tail, oedema \\
\hline 14 & NR2 & 1.59 & 0.33 & Survived but died suddenly on day 23 \\
\hline 15 & & 2.04 & 0.29 & Died on day 1 ; abdominal distension and subcutaneous haemorrhage \\
\hline 16 & & 1.14 & 0.30 & $\begin{array}{l}\text { Died } 30 \text { min after birth; abdominal distension and subcutaneous haemorrhage, half } \\
\text { open eye }\end{array}$ \\
\hline 17 & & 2.08 & 0.46 & Died on day 1 ; abdominal distension and subcutaneous haemorrhage \\
\hline 18 & & 1.54 & 0.25 & Died on day $2 ;$ abdominal distension and subcutaneous haemorrhage \\
\hline \multirow[t]{2}{*}{19} & & 1.02 & 0.21 & Survived but died suddenly on day 30 \\
\hline & Mean \pm SD & $1.42 \pm 0.4$ & $0.28 \pm 0.07$ & \\
\hline
\end{tabular}

higher than that of oocytes activated by electric stimulation. In contrast, the developmental potential of electrically stimulated oocytes was significantly higher in the R1 line.

Although the developmental potential of nucleartransferred oocytes into blastocysts was high (34-88\%), the proportion of blastocysts that developed into live young was extremely low (1-3\%) in all cell lines except the EGFP cell line, for which no live young were obtained. Moreover, 14 of 19 young obtained from NARA 7, 8, 10, 11, 12 and R1 cell lines died between $30 \mathrm{~min}$ and 2 days after birth. Although pathological analysis of the young was not performed, nine of 14 young, all males, had abdominal distension and large subcutaneous haemorrhages (Table 2 and Fig. 1a). One mouse with a half-open eye had an abdominal hernia (Fig. 1b), and another had a short tail and slight oedema over the entire body (Fig. 1c). The remaining five young survived but two of them, both from the NR2 cell line, died suddenly at days 23 and 30 after birth. The other three young (Fig. 1d), one from NARA 6 and two from NARA 9, are now 338-359 days old (17 March 2001) and all have normal fertility.

The mean body weight of young obtained with embryonic stem cells $(1.42 \pm 0.4 \mathrm{~g}, n=19)$ was not different from that of young obtained after transfer of F1 $(\mathrm{C} 57 \mathrm{BL} \times \mathrm{C} 3 \mathrm{H}) \times \mathrm{F} 1$ blastocysts that developed from zygotes in vitro $(1.34 \pm 0.1 \mathrm{~g}, n=11)$ (Table 2). The mass of the placentas derived from embryonic stem cells $(0.28 \pm 0.07 \mathrm{~g})$ was more than twice the normal value $(0.12 \pm 0.01 \mathrm{~g}, n=11)$.

\section{Discussion}

A number of cloned cows and sheep have been produced after nuclear transfer of nuclei from preimplantation embryos at the G1 stage to enucleated oocytes at the metaphase, or transfer of nuclei at an undetermined cell cycle stage to pre-activated oocytes (Campbell et al., 1996). However, cloned mice have been produced only by fusing nuclei at the G1/S (Tsunoda and Kato, 1997, 1998), G2 (Cheong et al., 1993) or M (Kwon and Kono, 1996) stages with enucleated oocytes at the metaphase. The cell cycle of nuclei from preimplantation mouse embryos can be synchronized by nocodazole treatment (Kato and Tsunoda, 1992) without reducing the developmental potential. When embryonic stem cells were cultured with $3 \mu \mathrm{g}$ nocodazole $\mathrm{ml}^{-1}$ for 3-6 h, most of the cells arising from the embryonic stem cell colony had metaphase chromosomes. After release from nocodazole culture, embryonic stem cells divided as preimplantation embryos within $1.5 \mathrm{~h}$ (Kato and Tsunoda, 1992). When embryonic stem cells, shortly after division, presumably at the G1/S stage, were fused with enucleated oocytes and re-nuclear transferred to fertilized embryos at the two-cell stage (Tsunoda and Kato, 1997) $20-74 \%$ developed into blastocysts but none of them developed into young (Y. Tsunoda and Y. Kato, unpublished). The problem with this procedure was the low fusion rate (16-20\%) due to the small size of embryonic stem cells at the G1 stage. Thus, embryonic stem cells at the metaphase were used before cell division as reported by 

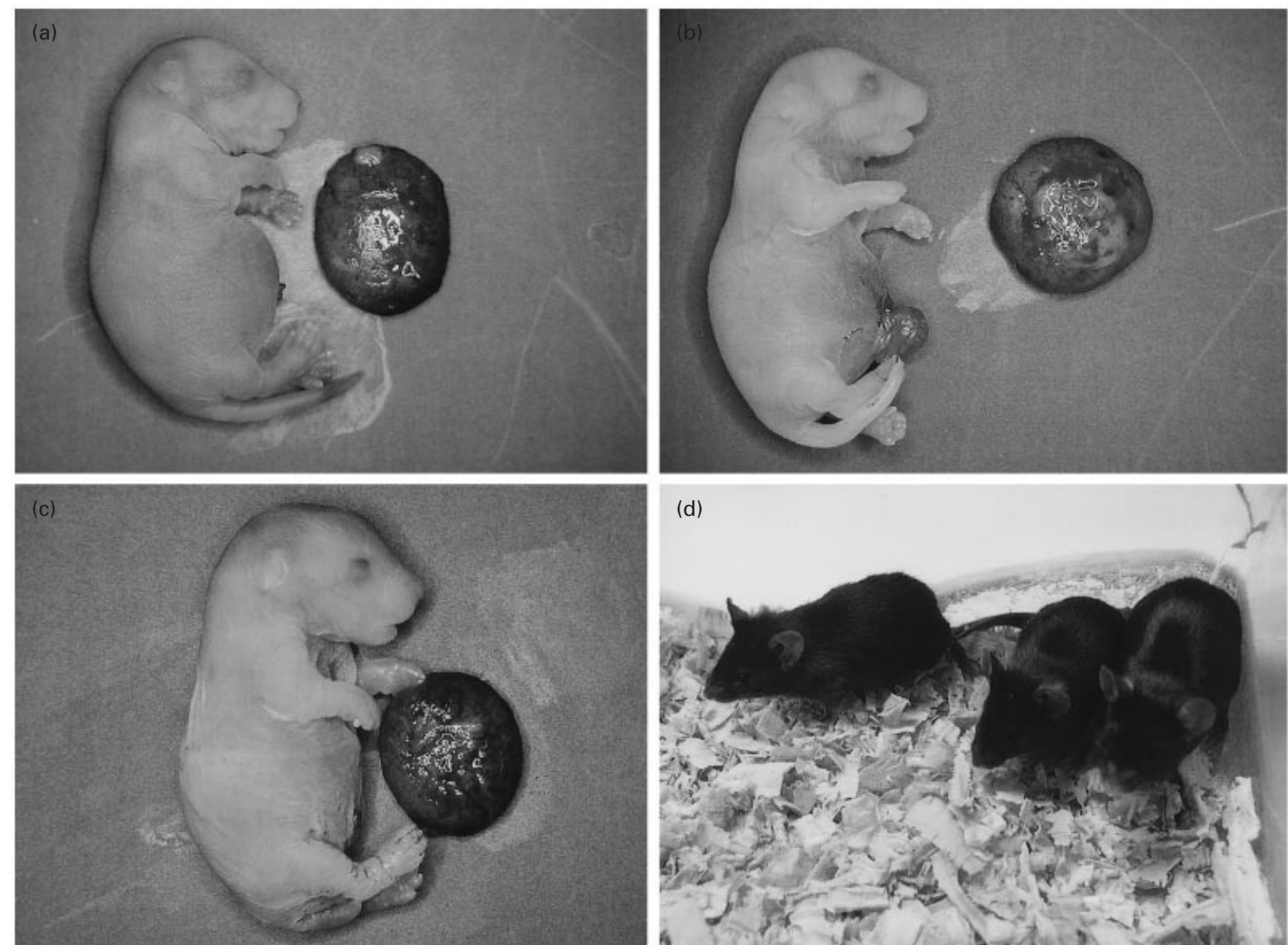

Fig. 1. Living young mice numbers (a) 6, (b) 2 and (c) 13 (see Table 2) immediately after recovery on day 19.5. (a) Mouse with abdominal distention and large subcutaneous haemorrhages. (b) Mouse with half-open eye and abdominal hernia. (c) Mouse with short tail and slight oedema over entire body. (d) Healthy live young (numbers 1, 4 and 5) with normal fertility.

Amano et al. (2001). Other studies (Wakayama et al., 1999; Rideout et al., 2000) and the present study have revealed that cloned mice can be obtained after nuclear transfer of wild type and targeted embryonic stem cells; however, the rate of development into live young after fusion with or after injection into enucleated oocytes was low even compared with birth rates after somatic nuclear transfer in cows (10-83\%; Pennisi and Vogel, 2000). As the cloning rates from mouse cumulus cells (Wakayama et al., 1998; Kato et al., 1999) and tail-tip cells (Wakayama and Yanagimachi, $1999 b)$ are also low using either the injection or fusion methods, the nuclear transfer technique might be inadequate in mice compared with cows.

Most of the live young obtained after nuclear transfer of embryonic stem cells died soon after birth. Rideout et al. (2000) reported that genetic background was an important factor in cloning efficiency and postnatal death as $129 \mathrm{~F} 1$ embryonic stem cells, rather than C57BL F1 cells, were the most efficient. However, the results of the present study demonstrate that the incidence of postnatal death was also different among embryonic stem cell lines with the same genetic background. This finding indicates that cells with different characteristics are mixed in a single cell line.

Considering the heavy masses of placentas derived from embryonic stem cells, the epigenetic modifications of embryonic stem cells during in vitro culture for establishment and passage might be the main reason for the abnormalities and postnatal death of the young. The abnormalities and postnatal death observed in the present study include the same features as the perinatal problems in cloned cows (Hill et al., 1999; Kato et al., 2000), the mechanisms of which have yet to be elucidated. To date, 32 cloned cows have been obtained after nuclear transfer of somatic cells from various tissues, 15 of which died around the time of parturition (Kato et al., 1998, 2000). The sudden death of cloned offspring as observed in the present study has also been reported in cows (Renard et al., 1999). Gene expression and protein analysis studies in cloned embryos and fetuses are required to investigate the reasons for such abnormalities and perinatal death of young. Studies on 
the technical improvement of nuclear transfer are also necessary to develop a reliable cloning technology for mice.

The authors would like to thank A. Surani for providing NR2, A. Nagy and W. Abramow-Newerly for R1, and M. Okabe and M. Ikawa for the EGFP embryonic stem cell lines. This work was supported by grants from the Ministry of Education, Science, and Culture (11480250, 12358014), the Human Science Foundation, the Research Grant (10B-1) for Nervous and Mental Disorders from the Ministry of Health and Welfare, the Program for Promotion of Basic Research Activities for Innovative Biosciences (PROBRAIN), and a Research Fellowship of the Japan Society for the Promotion of Science for Young Scientists to T. Amano.

\section{References}

Amano T, Nakamura K, Tani T, Kato Y and Tsunoda Y (2000) Production of mice derived entirely from embryonic stem cells after injecting the cells into heat treated blastocysts Theriogenology 53 1449-1458

Amano T, Tani T, Kato $\mathbf{Y}$ and Tsunoda $\mathbf{Y}$ (2001) Mouse cloned from embryonic stem (ES) cells synchronized metaphase with nocodazole Journal of Experimental Zoology 289 139-145

Campbell KHS, Loi P, Otaegui PJ and Wilmut I (1996) Cell cycle coordination in embryo cloning by nuclear transfer Reviews of Reproduction 1 40-46

Cheong HT, Takahashi Y and Kanagawa H (1993) Birth of mice after transplantation of early cell-cycle-stage embryonic nuclei into enucleated oocytes Biology of Reproduction 48 958-963

Friedrich G and Soriano P (1991) Promoter traps in embryonic stem cells: a genetic screen to identify and mutate developmental genes in mice Genes and Development 5 1513-1523

Hill JR, Roussel AJ, Cibelli JB et al. (1999) Clinical and pathologic features of cloned transgenic calves and fetuses (13 case studies) Theriogenology 51 1451-1465

Kato $\mathbf{Y}$ and Tsunoda $\mathbf{Y}$ (1992) Synchronous division of mouse two-cell embryos with nocodazole in vitro. Journal of Reproduction and Fertility 95 39-43

Kato Y, Tani T, Sotomaru Y, Kurokawa K, Kato J, Doguchi H, Yasue H and Tsunoda Y (1998) Eight calves cloned from somatic cells of a single adult Science 282 2095-2098

Kato Y, Yabuuchi A, Motosugi N, Kato J and Tsunoda Y (1999) Developmental potential of mouse follicular epithelial cells and cumulus cells after nuclear transfer Biology of Reproduction $\mathbf{6 1}$ 1110-1114

Kato $\mathbf{Y}$, Tani T and Tsunoda $\mathbf{Y}(2000)$ Female and male calves cloned from various somatic cell types of adults, newborns and fetuses Journal of Reproduction and Fertility 120 231-237

Kwon OY and Kono T (1996) Production of identical sextuplet mice by transferring metaphase nuclei from four-cell embryos Proceedings National Academy of Sciences USA 93 13010-13013

Nagy A, Gocza E, Diaz EM, Prideaux VR, Ivanyi E, Markkula M and Rossant J (1990) Embryonic stem cells alone are able to support fetal development in the mouse Development 110 815-821

Okabe M, Ikawa M, Kominami K, Nakanishi T and Nishimune Y (1997) 'Green mice' as a source of ubiquitous green cells FEBS Letters $\mathbf{5}$ 313-319

Pennisi E and Vogel G (2000) Clones: a hard act to follow Science 288 1723-1727

Renard JP, Chastant S, Chesne P, Richard C, Marchal J, Cordonnier N, Chavatte $\mathbf{P}$ and Vignon $\mathbf{X}$ (1999) Lymphoid hypolasia and somatic cloning Lancet 353 1489-1491

Rideout WM, III, Wakayama T, Wutz A, Eggan K, Jckson-Grusby L, Dausman J, Yanagimachi R and Jaenisch R (2000) Generation of mice from wild-type and targeted ES cells by nuclear cloning Nature Genetics 24 109-110

Tsunoda Y and Kato Y (1997) Full-term development after transfer of nuclei from 4-cell and compacted morula stage embryos to enucleated oocytes in the mouse Journal of Experimental Zoology 278 250-254

Tsunoda Y and Kato Y (1998) Not only inner cell mass cell nuclei but also trophectoderm nuclei of mouse blastocysts have a developmental totipotency Journal of Reproduction and Fertility 113 181-184

Wakayama T and Yanagimachi R (1999) Cloning of male mice from adult tail-tip cells Nature Genetics 22 127-128

Wakayama T, Perry AC, Zuccotti M, Johnson KR and Yanagimachi R (1998) Full-term development of mice from enucleated oocytes injected with cumulus cell nuclei Nature 394 369-374

Wakayama T, Rodriguez I, Perry AC, Yanagimachi R and Mombaerts P (1999) Mice cloned from embryonic stem cells Proceedings National Academy of Sciences USA 96 14984-14989

Whittingham DG (1971) Culture of mouse ova Journal of Reproduction and Fertility Supplement 14 7-21

Received 2 October 2000.

First decision 17 November 2000.

Accepted 7 December 2000. 